\title{
Temporal variability in patterns of association among fish species on coral patch reefs
}

\author{
P. F. Sale*, W. J. Steel \\ School of Biological Sciences, University of Sydney, Sydney, NSW 2006, Australia
}

\begin{abstract}
Data on the distribution of 25 common species of fish over 20 patch reefs located in a coral reef lagoon (Great Barrier Reef) were collected by 20 visual censuses over 10 yr. Associations among the 25 species were examined by cluster analysis. The overall pattern of association changed substantially from census to census. So too did the relationships among small subsets of the 25 species which were tightly associated at one or more censuses. The degree of association among groups of species was compared with that expected under a null model of non-interactive recruitment of fish to patch reefs. Species in many apparently closely associated small groups were less strongly associated than expected under the null model, suggesting that species react differently to the habitats offered by the patch reefs, or respond negatively to each other's presence. Results are discussed in the light of other information on the structure of these assemblages of fish.
\end{abstract}

\section{INTRODUCTION}

When species occur in an archipelago, the islands which comprise it may be considered replicate locations in which the structure of biotic communities can be examined. Real, oceanic archipelagoes have been viewed in this way for a long time, and the seminal book by MacArthur \& Wilson (1967) led to considerable interest in island studies. Emphasis has been placed on distribution of island birds, insects, or terrestrial plants, and most analyses have used the presence/absence data available in species lists (Simberloff 1974, Diamond 1975).

Ecologists were quick to realize that the usefulness of archipelagoes extended to habitat islands. Wherever the environment is patchy, providing islands supporting populations of the chosen biota scattered within a sea of inhospitable habitat, island approaches can and have been used. Thus, trees, clumps of mangrove and patches of Spartina have all been considered islands for insects (Simberloff \& Wilson 1969, Strong \& Rey 1982, Rey 1984). Lakes and ponds have been viewed as islands for fish or zooplankton (Magnusson 1976). Mountain tops have been islands for mammals (Wilcox

\footnotetext{
- Present address: Department of Zoology, University of New Hampshire, Durham, New Hampshire 03824, USA
}

et al. 1986) and alpine plants (Riebesell 1982), and the mounds of soil turned up by badgers in prairies have been islands for certain fugitive weeds (Platt \& Weis 1985).

Coral reefs are remarkably patchy on a wide range of scales from the geographic, to a scale of centimeters, and many of their inhabitants are quite habitatspecific. Thus, it is not surprising that island approaches have been used, sometimes explicitly (Molles 1978), sometimes implicitly (Smith \& Tyler 1972, 1975, Sale \& Dybdahl 1975, 1978, Goldman \& Talbot 1976, Talbot et al. 1978, Bohnsack \& Talbot 1980, Gladfelter et al. 1980, Shulman et al. 1983, Sale \& Douglas 1984). In many of these coral reef studies, because of the nature of the environment and the life histories of the species examined, it has been possible to work at small scales, examining patterns of species abundance as well as simple presence or absence.

Coral reef fish almost universally have a bipartite life cycle with a dispersive pelagic larval stage, followed by a sedentary juvenile and adult life (Sale 1980a). Small patches of reef habitat, $1 \mathrm{~m}$ or less in diameter, can act as islands for many species when they are separated from similar patches by a few meters of open sand or other unsuitable habitat. These 'islands' differ in one important respect from the islands usually dealt with in biogeographic studies. The population of a species present on an isolated patch of reef only grows through 
immigration of additional settling larvae, and all reproductive effort is exported via the pelagic larval stage to other patches.

The degree to which fish form assemblages with a predictable and persistent structure on patches of reef habitat has been of central concern to reef fish ecologists since the mid-1970's (Smith \& Tyler 1972, Sale \& Dybdahl 1975, Talbot et al. 1978, Gladfelter et al. 1980, Shulman et al. 1983, among others). Since fish join resident assemblages as young individuals settling from the plankton we might expect biotic interactions within the assemblage to play a strong structuring role, determining which species might occur together and in what relative proportions. In 1977 we commenced a long-term study to evaluate the structure and organization of such assemblages, monitoring 20 assemblages of reef fish occurring on 20 small patch reefs in a shallow reef lagoon. We used a visual census procedure (Sale \& Douglas 1981) which accurately determines the number of individuais of each species present, although a small number of cryptic species are not detected. The patch reefs have been disturbed in no way other than by the visits of divers for censusing. Assemblages were censused 20 times until July 1986. The resulting data base includes abundances as well as records of the presence or absence of each of about 150 species of fish.

Analyses based on the first 8 censuses disclosed that the structure of these assemblages varied considerably through time, as individuals arrived or were lost, and there was little success in relating aspects of structure (species richness, abundance of particular species) to aspects of the habitat (other than surface area) offered by particular reefs (Sale \& Douglas 1984). Subsequent simulation work, using the data base compiled from 10 censuses over 4 yr to 1981, confirmed that the structure of the assemblages was largely, though certainly not totally, accounted for by a null model of random recruitment of fish to reefs (Sale \& Steel 1986). In that work the emphasis was on number of species, species composition, and the relative abundance of individual species present.

The present paper uses the data base, now expanded to 20 censuses, to determine whether there are patterns of association among species and, if so, whether the patterns are stronger than might be expected under a model of chance recruitment. Both positive associations, in which species are distributed similarly across the reefs, and negative associations, in which species tend to be found on different reefs, are considered. Secondly, given that some such associations do occur, we explore whether they tended to persist through the $10 \mathrm{yr}$ of the study Our general aim is to establish whether there is evidence of permissible combinations' (cf. Diamond 1975) - groups of species which tend to occur together and resist invasion by certain other species - among the species which colonize these habitat islands

\section{METHODS}

This paper is based on visual censuses of fish on each of 20 undisturbed lagoonal patch reefs at One Tree Reef, Great Barrier Reef $\left(23^{\circ} 31^{\prime} \mathrm{S}, 152^{\circ} 06^{\prime} \mathrm{E}\right)$. Distributions and abundances of 25 species of fish at each of 20 censuses from August 1977 to July 1986 were examined for possible associations. The 25 species represent the most abundant from a total pool of ca 150 species recorded in our censuses (Sale \& Douglas 1984) and comprise more than $90 \%$ of all individuals. Details of the patch reefs (size, location, etc.) and the censusing procedure are in Sale \& Douglas (1984).

At each census, average linkage cluster analysis (cf. Sneath \& Sokal 1973, Clifford \& Stephensen 1975, Pielou 1984) was used to identify associations among the 25 species of fish. The index of association between each pair of species used in our analysis was the proportional similarity of distribution across the 20 patch reefs (Kohn \& Riggs 1982). Proportional similarity was measured as:

$$
\mathrm{PS}_{i j}=1-0.5 \sum_{n=1}^{r}\left|\mathrm{P}_{i k}-\mathrm{P}_{j k}\right|
$$

where $\mathrm{P}_{i k}=$ the proportion of species $i$ on reef $k_{i} \mathrm{P}_{j k}=$ the proportion of species $j$ on reef $k_{i} r=$ the number of reefs. A value for $\mathrm{PS}_{i j}$ of 1 indicates $100 \%$ similarity (i.e. the 2 species have exactly the same relative abundance across reefs) and 0 indicates complete dissimilarity. We have multiplied PS values by 100 to express them as percentages.

The $N \times N$ matrix ( $N=$ number of species) of similarity values forms the raw material for the cluster analysis which is agglomerative and stepwise (e.g. Sneath \& Sokal 1973. Clifford \& Stephenson 1975, Pielou 1984). A working description is as follows:

Initially, that pair of species showing the highest PS value is fused. Then the similarity of each other species to this cluster is determined as the mean of that species similarity to each of the already fused species

The highest PS value is then selected for the next fusion. This may be the fusion of a second pair of species, or the joining of a third species to the initial cluster. Average similarity values are again calculated and this sequence of steps is continued until all species have fused as a single group.

The procedure permits presentation of a dendrogram showing successive fusions of groups of species and the level of similarity at which they take place. The method is computationally straightforward and logically ap- 
pealing while still generating dendrograms which reduce the problem of chaining evident in single linkage clustering methods. We derived dendrograms for each of the 20 censuses.

In order to assess the significance of the clusters we found, we modified the procedures proposed by Harper (1978) and Strauss (1982) for presence/absence data. For each census we constructed random data matrices (25 species $\times 20$ reefs), calculated similarity matrices $(25 \times 25)$ from these, and then did cluster analyses on these matrices. This procedure was repeated 15 times to give 15 random dendrograms for each census.

We used a simple non-interactive model of assemblage formation (proposed in Sale \& Douglas 1984 and examined in Sale \& Steel 1986) to construct the random data matrices. The real data at each census were set out as a 20 row by 25 column matrix of numbers in which each row represents counts of fish of each species present at each of 20 reefs, and each column represents counts of individuals of a single species present on the reefs. Row totals represent the number of fish of all species present at a single reef, while column totals represent the abundance of a single species over all reefs. Row totals vary considerably among reefs because reefs are of different size and attractiveness to fish, while column totals also vary considerably because some species are more common on average than others.

We generated randomized matrices while preserving these row and column totals. In this way we maintained the tendency for certain reefs to contain more fish than
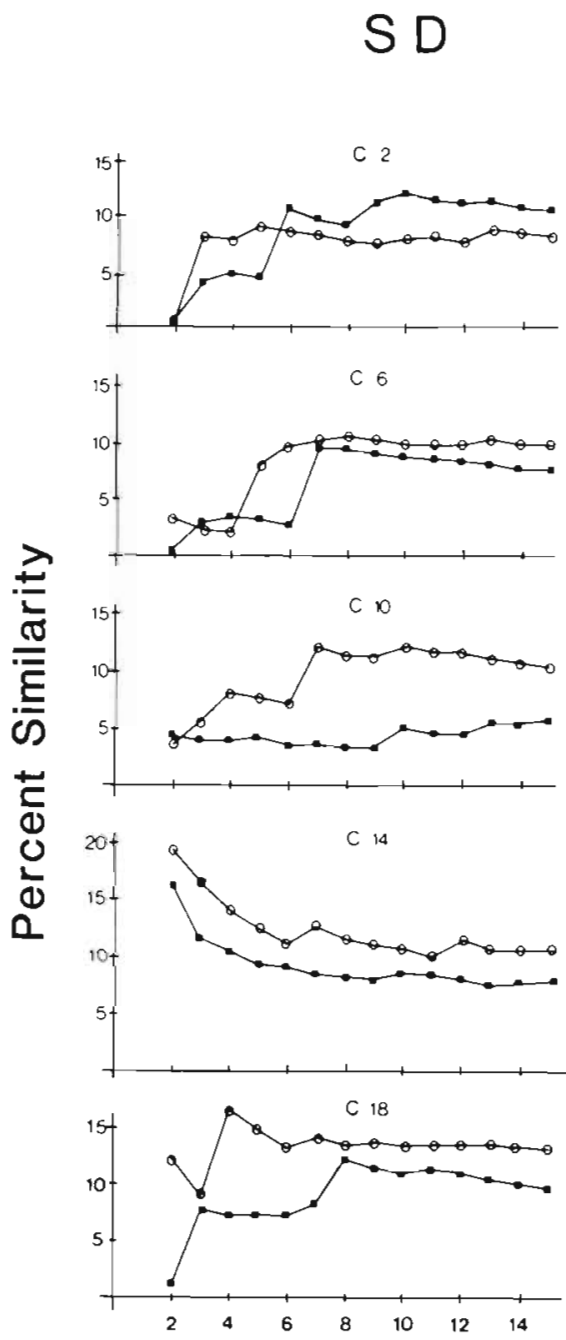

\section{Mean}
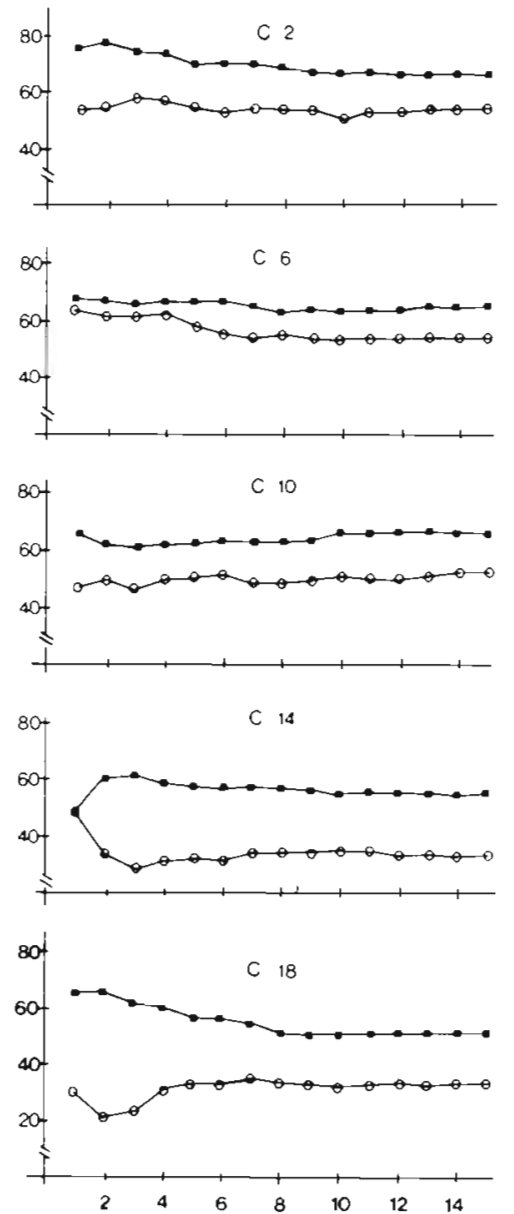

\section{No. of Simulations}

Fig. 1. Mean and standard deviation of the percent similarity for each of 2 groups of species, as calculated from increasing number of simulations. See text for further details. The 2 groups of species illustrated were typical examples. Groups chosen were (1) Gobiodon quinquestrigata and Dascyllus aruanus (o) and (2) Asterpteryx semipunctatus, Pomacentrus sp. and Thalassoma lunare (-) 

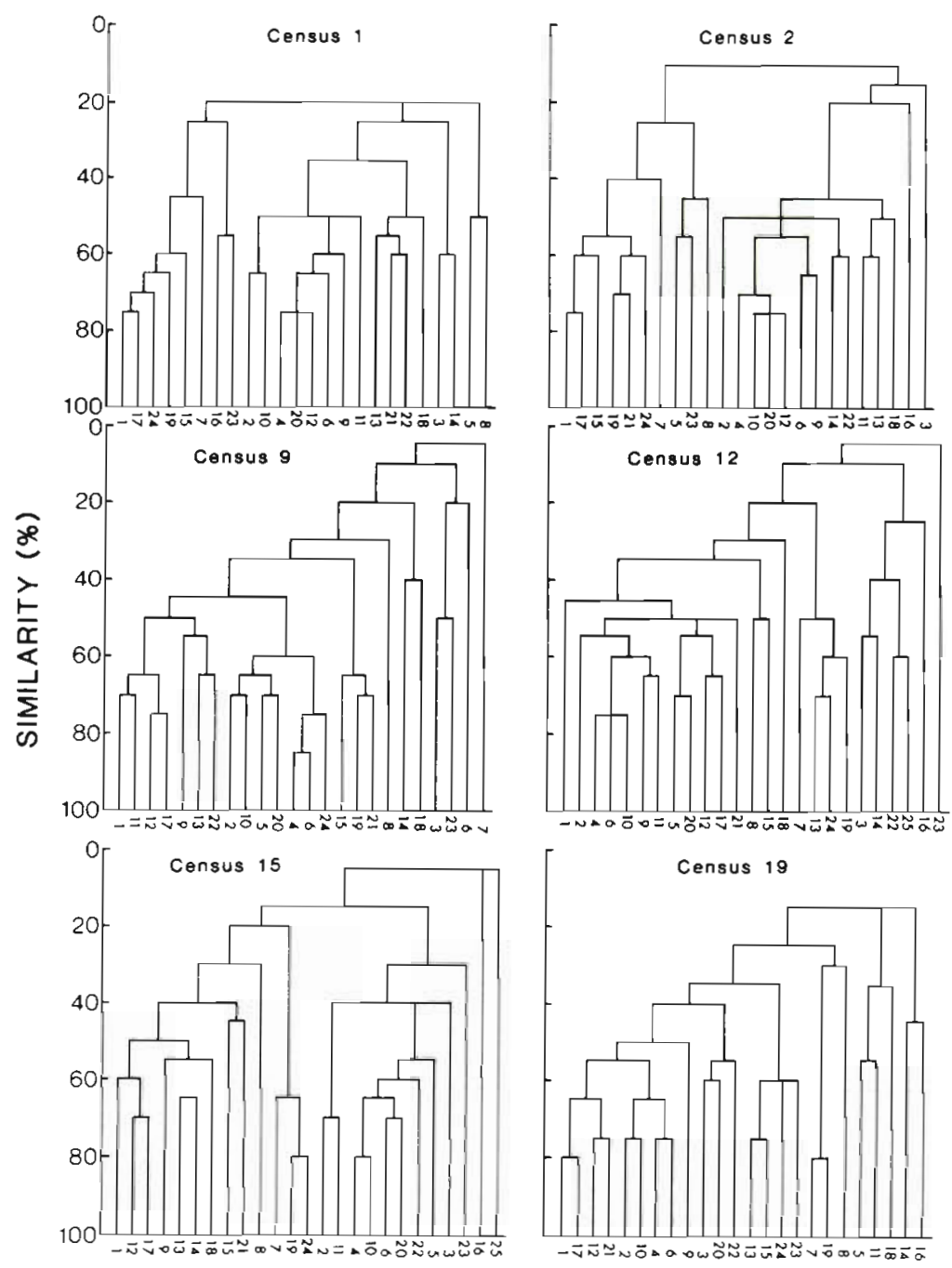

SPECIES REFERENCE NOS.

Fig. 2. Six examples of the fusions obtained in dendrograms. Levels of the association are rounded up to nearest $5 \%$. See text for details. Fish species are: (1) Atrosalarius fuscus; (2) Ecsenius mandibularis; (3) Petroscirtes fallax; (4) Asteropteryx semipunctatus; (5) Eviota queenslandica; (6) Amblygobius phalaena; (7) Gobiodon okinawe; (8) Gobiodon quinquestrigata; (9) Cirrhilabrus sp.; (10) Coris variegata; (11) Labroides dimidiatus; (12) Thalassoma lunare; (13) Acanthochromis polyacanthus; (14) Chromis nitida; (15) Dascyllus aruanus; (16) Dascyllus reticulatus; (17) Pomacentrus amboinensis; (18) Pomacentrus pavo; (19) Pomacentrus moluccensis; (20) Pomacentrus sp.; (21) Scarus spp.; (22) Apogon doederleini; (23) Apogon cyanosoma; (24) Cheilodipterus quinquelineata; (25) Apogon gracilis

others, as well as the pattern of relative abundance among the totals of the 25 species. Using the row and column totals to generate probabilities we randomly selected individual fish and assigned them to randomly selected reefs. At each selection step probabilities were adjusted until all fish had been allocated and all reefs contained the correct total numbers.

This procedure is closely analogous to that used by Connor \& Simberloff (1979) to generate non-interactive matrices of presence/absence data. However, because the cell values can vary substantially rather than being limited to 0 or 1 as in presence/absence data, the number of potential combinations is very great, and the criticism by Diamond \& Gilpin (1982) that there was a limited number of null combinations in the technique of Connor \& Simberloff (1979) is not as relevant.

Matrices generated in this way preserve the total abundance of individual species and the sizes of assemblages. Beyond these constraints, the distribution of each species across reefs is random and independent of that of other species. It follows that the mean degree of association computed from 15 such randomized matrices can be used as a measure of the degree of association likely by chance combinations among that group. 
Fifteen simulations only were carried out as the mean association among members of any given grouping usually stabilized after 10 simulations, and the standard deviation of the mean was stabilizing after 15 simulations (examples in Fig. 1).

The average similarity of any given pair or grouping in the simulated data was calculated and compared to the similarity of those same species obtained from the real dendrogram. This was done (using Student's $t$ ) by testing whether an observed similarity value could be considered a member of the population of values for the particular comparison generated by the simulations (Sokal \& Rohlf 1981, p. 231).

\section{RESULTS}

\section{General patterns of clustering}

Over the 20 censuses, species varied in the strength of their associations with one another. Some pairs of species were closely associated and clustered early while others were very dissimilar in pattern of association and clustered only at low levels of similarity. Fig. 2 shows 6 representative dendrograms.

In 8 of the 20 censuses, inspection of the dendrograms suggested divisions of the species into 2 or 3 large groups at moderate levels of similarity, but the species contained within each group varied from cen- sus to census (compare census Nos. 1, 2, and 15 in Fig. 2). At the remaining 12 censuses the pattern was less clear. Either there were numerous small groups which did not fuse until high levels of dissimilarity were reached (e.g. census Nos. 12 and 19 in Fig. 2) or a large group was built up by successive chaining of added species at successively greater degrees of dissimilarity (e.g. census No. 9 in Fig. 2). Because of this failure of overall pattern to persist across censuses, we turned to examining the degree of association within selected smaller groupings of species.

\section{Small groupings of species}

We examined all clusters which formed at association levels greater than the overall average (ca $50 \%$ similarity). They averaged only $3.15 \pm 0.11 \mathrm{SE}$ species per cluster (Table 1). At still higher levels of association (> $65 \%$ similarity) this reduced to $2.35 \pm 0.08 \mathrm{SE}$ species per cluster. We concluded there were no large groups of species with strongly similar patterns of distribution across the patch reefs at any census.

We also looked at species or groups of species which were markedly dissimilar in distribution. Census No. 2 (Fig. 2) was exceptional in that the final fusion was of 2 groups of species of approximately equal size. In all other censuses, 1 to 3 very dissimilar species remained after all others had been fused into a single group

Table 1. Sizes of clusters of species formed at specified levels of similarity. Each entry represents the number of species in a unique cluster at each census, although species included in a cluster at a higher level of similarity may be joined with other species to form a larger cluster at a lower level of similarity. The significance of each cluster formed at $70 \%$ or more similarity is also shown $(\cdot p<0.05 ;$ ns: $p>0.05)$. See text for further details

\begin{tabular}{|c|c|c|c|c|c|}
\hline \multirow[t]{2}{*}{ Census } & \multicolumn{5}{|c|}{ Level of similarity at which cluster is formed } \\
\hline & $65-70 \%$ & $70-75 \%$ & $75-80 \%$ & $80-85 \%$ & $>85 \%$ \\
\hline 1 & 3 & $2^{\text {ns }} \cdot 3^{\text {ns }}$ & - & - & \\
\hline 2 & 2,4 & $2^{\text {ns }}, 3^{\text {ns }}$ & - & - & \\
\hline 3 & 2,4 & - & - & $2^{\text {ns }} \cdot 3^{\text {ns }}$ & \\
\hline 4 & 2,4 & $2^{\text {ns }}, 2^{\text {ns }}$ & $3^{\text {ns }}$ & $2^{\text {ns }}$ & \\
\hline 5 & $2,2,3$ & $2^{\text {ns }}$ & $2^{\text {ns }}$ & - & $N$ \\
\hline 6 & 3 & $2^{\text {ns }}$ & $2^{\cdot}$ & - & \\
\hline 7 & 3 & - & - & - & $\mathrm{O}$ \\
\hline 8 & $2,2,4$ & $2^{n s}, 3^{n s}$ & $2^{\text {ns }} \cdot 2^{\text {ns }}$ & - & \\
\hline 9 & $2,2,2,2$ & $2^{\text {ns }}, 3^{\circ}$ & - & $2^{\text {ns }}$ & $N$ \\
\hline 10 & $2,2,2,4$ & $2^{\text {ns }}, 2^{\text {ns }}$ & - & - & \\
\hline 11 & $2,2,3,3$ & $2^{n s} \cdot 2^{n s}$ & - & - & $E$ \\
\hline 12 & 2,2 & $3^{n s}$ & - & - & \\
\hline 13 & 2,4 & $2^{\text {ns }}$ & $2^{\text {ns }}$ & - & \\
\hline 14 & - & $2^{*}$ & $2^{\text {ns }}$ & - & \\
\hline 15 & $2,2,2$ & - & $2^{\text {ns }} \cdot 2^{\text {ns }}$ & - & \\
\hline 16 & $2,2,4$ & $2^{\text {ns }} \cdot 3^{\text {ns }}$ & $2^{\text {ns }}$ & - & \\
\hline 17 & $2,2,3$ & - & $2^{\text {ns }}$ & - & \\
\hline 18 & $2,2,2,3$ & $2^{\text {ns }}$ & - & - & \\
\hline 19 & - & $2^{\text {ns }}, 2^{\text {ns }}, 2^{\bullet}, 2^{*}$ & $2^{n s}, 2^{\text {ns }}$ & - & \\
\hline 20 & 3,4 & $2^{\mathrm{ns}}, 2^{\mathrm{ns}}$ & $2^{*}$ & - & \\
\hline
\end{tabular}


Table 2. Level of similarity at which the final fusion of species takes place and the sizes of the groups fusing at that level. Note that not all 25 species were present at some censuses. (Rounding of similarity values up to nearest $5 \%$ means that fusion of 3 clusters occurs in some censuses)

\begin{tabular}{|c|c|c|c|c|c|}
\hline \multirow{2}{*}{$\begin{array}{c}\text { Census } \\
1\end{array}$} & \multirow{2}{*}{$\begin{array}{c}\text { No. species } \\
\text { present } \\
24\end{array}$} & \multicolumn{3}{|c|}{$\begin{array}{l}\text { No. species in } \\
\text { clusters fusing }\end{array}$} & \multirow{2}{*}{$\begin{array}{c}\text { Similarity } \\
\qquad 15 \%\end{array}$} \\
\hline & & 2 & 8 & 14 & \\
\hline 2 & 24 & 10 & 14 & & $10 \%$ \\
\hline 3 & 25 & 1 & 1 & 23 & $5 \%$ \\
\hline 4 & 25 & 1 & 24 & & $5 \%$ \\
\hline 5 & 25 & 4 & 21 & & $10 \%$ \\
\hline 6 & 25 & 1 & 2 & 22 & $10 \%$ \\
\hline 7 & 25 & 1 & 3 & 21 & $10 \%$ \\
\hline 8 & 24 & 1 & 23 & & $5 \%$ \\
\hline 9 & 24 & 1 & 23 & & $5 \%$ \\
\hline 10 & 24 & 1 & 23 & & $5 \%$ \\
\hline 11 & 25 & 5 & 20 & & $5 \%$ \\
\hline 12 & 25 & 1 & 24 & & $5 \%$ \\
\hline 13 & 25 & 1 & 1 & 23 & $5 \%$ \\
\hline 14 & 25 & 1 & 24 & & $5 \%$ \\
\hline 15 & 25 & 1 & 1 & 23 & $5 \%$ \\
\hline 16 & 24 & 2 & 22 & & $10 \%$ \\
\hline 17 & 25 & 1 & 24 & & $5 \%$ \\
\hline 18 & 25 & 1 & 2 & 22 & $5 \%$ \\
\hline 19 & 24 & 2 & 3 & 19 & $15 \%$ \\
\hline 20 & 23 & 1 & 22 & & $5 \%$ \\
\hline
\end{tabular}

(Table 2). These most dissimilar species were different species at each census (see species $7,16,23$, and 25 in Fig. 2).

\section{Persistence of patterns of association}

Although preliminary perusal of the dendrograms indicated no strong persistence of pattern of associations, it remains possible that certain small groups of species may remain strongly positively or negatively associated from one census to another. Species could remain positively associated by maintaining a constant pattern of distribution across patch reefs from census to census, or by altering their distributions in similar ways. Species could remain negatively associated even if their patterns of distribution changed among censuses so long as in changing they did not converge. We used the groups of species identified in Tables 1 and 2 to seek evidence of persistence of associations of small groups.

Consider initially those clusters that formed with association levels greater than $80 \%$ similarity. This occurred at only census Nos. 3, 4, and 9 (Table 1). At census No. 3, 2 separate clusters formed at greater than $80 \%$ similarity, the first with 2 species and the second with 3 species. By working from census to census we followed the relationships among the species in each cluster for the full 20 censuses.

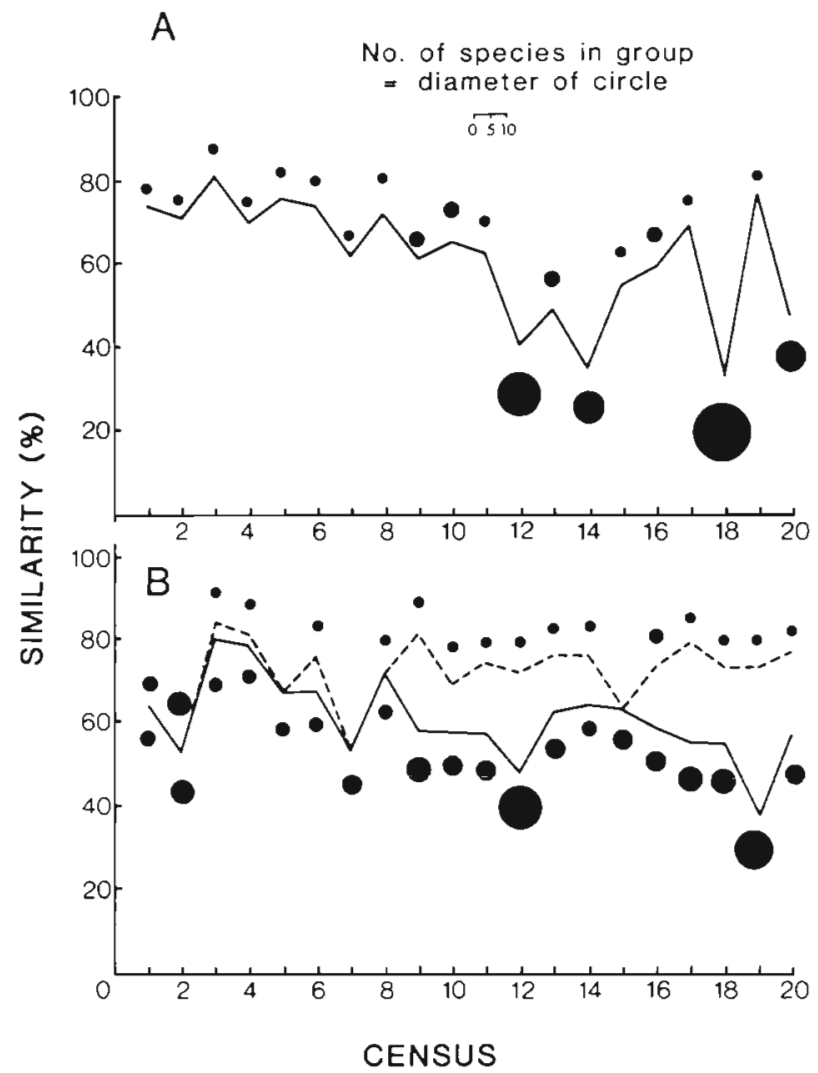

Fig. 3. Records of degree of association within 3 groups of species selected because of their high levels of similarity at 1 census. Graph records the level of similarity at which the chosen set of species first clusters together at each census. Because additional species are included in some of these clusters, the size of each cluster formed is represented as the diameter of the adjacent circle. (A) Clustering of Atrosalarius fuscus and Pomacentrus amboinensis; (B) Clustering of Asteropteryx semipunctatus and Amblygobius phalaena (dashed line), and both of these with Pomacentrus sp. (solid line)

The 2 species in the first cluster were Atrosalarius fuscus (Blenniidae) and Pomacentrus ambionensis (Pomacentridae). The pattern of association for these 2 species across all the censuses is shown in Fig. 3A. A. fuscus and $P$. amboinensis maintain a high level of association (ca 60 to $80 \%$ similarity) for the first 11 censuses, but then fluctuate in degree of association from low $(32 \%)$ to high $(76 \%)$ similarity values for the remainder of the study. For the first 8 censuses and at census Nos. 17 and 19, A. fuscus is the first species to fuse with $P$, amboinensis forming a separate 2 -species cluster. They are, thus, more similar to one another than to any other species. At the other censuses, however, they each join with other species before forming a single larger cluster (see census Nos. 9, 12, and 15 in Fig. 2). At these censuses they are less similar to one another than either is to other species. 
Table 3. Average level of association (as percent similarity) and its Standard Error across all censuses, of the 18 groups of species that formed clusters at high levels of similarity ( $>70 \%$ in Table 1$)$ at 1 or more censuses ( $n=20$ censuses in the study). Also listed are the highest ( $\mathrm{Max}$ ) and the lowest (Min) level of similarity at which the group fused and the census (Cens) at which this occurred

\begin{tabular}{|c|c|c|c|c|c|c|}
\hline Group & \multicolumn{2}{|c|}{ Species (reference no. and name) } & Mean & SE & Max (Cens) & Min (Cens) \\
\hline 1 & $\begin{array}{l}4 \\
6\end{array}$ & $\begin{array}{l}\text { Asteropteryx semipunctatus } \\
\text { Amblygobius phalaena }\end{array}$ & 71.9 & 1.9 & $84.0(3)$ & $53.0(2)$ \\
\hline 2 & $\begin{array}{r}1 \\
17\end{array}$ & $\begin{array}{l}\text { Atrosalarius fuscus } \\
\text { Pomacentrus amboinensis }\end{array}$ & 61.3 & 3.2 & $81.0(3)$ & $32.5(18)$ \\
\hline 3 & $\begin{array}{r}4 \\
6 \\
20\end{array}$ & $\begin{array}{l}\text { A. semipunctatus } \\
\text { A. phalaena } \\
\text { Pomacentrus sp. }\end{array}$ & 60.5 & 2.2 & $80.0(3)$ & $48.0(12)$ \\
\hline 4 & $\begin{array}{r}4 \\
10\end{array}$ & $\begin{array}{l}\text { A. semipunctatus } \\
\text { Coris variegata }\end{array}$ & 59.5 & 2.4 & $76.0(16)$ & $32.8(20)$ \\
\hline 5 & $\begin{array}{r}4 \\
6 \\
10\end{array}$ & $\begin{array}{l}\text { A. semipunctatus } \\
\text { A. phalaena } \\
\text { C. variegata }\end{array}$ & 57.7 & 2.2 & $73.5(16)$ & $32.8(20)$ \\
\hline 6 & $\begin{array}{r}2 \\
10\end{array}$ & $\begin{array}{l}\text { Ecsenius mandibularis } \\
\text { C. variegata }\end{array}$ & 54.7 & 2.5 & $72.0(19)$ & $35.1(14)$ \\
\hline 7 & $\begin{array}{r}1 \\
21\end{array}$ & $\begin{array}{l}\text { A. fuscus } \\
\text { Scarus spp. }\end{array}$ & 47.1 & 3.7 & $74.0(20)$ & $16.9(7)$ \\
\hline 8 & $\begin{array}{r}4 \\
20 \\
12\end{array}$ & $\begin{array}{l}\text { A. semipunctatus } \\
\text { Pomacentrus sp. } \\
\text { Thalassoma lunare }\end{array}$ & 44.9 & 3.5 & $71.5(1)$ & $10.4(15)$ \\
\hline 9 & $\begin{array}{l}11 \\
12\end{array}$ & $\begin{array}{l}\text { Labroides dimidiatus } \\
T \text { lunare }\end{array}$ & 44.2 & 4.0 & $73.0(10)$ & $10.4(15)$ \\
\hline 10 & $\begin{array}{l}13 \\
22\end{array}$ & $\begin{array}{l}\text { Acanthochromis polyacanthus } \\
\text { Apogon doederleini }\end{array}$ & 43.5 & 5.1 & $74.0(11)$ & $6.8(12)$ \\
\hline 11 & $\begin{array}{r}7 \\
19\end{array}$ & $\begin{array}{l}\text { Gobiodon okinawe } \\
\text { P. moluccensis }\end{array}$ & 39.9 & 5.1 & $78.0(19)$ & $3.2(10)$ \\
\hline 12 & $\begin{array}{l}12 \\
21\end{array}$ & $\begin{array}{l}T \text { lunare } \\
\text { Scarus spp. }\end{array}$ & 39.6 & 3.3 & $73.0(19)$ & $8.0(2)$ \\
\hline 13 & $\begin{array}{l}13 \\
17\end{array}$ & $\begin{array}{l}\text { A. polyacanthus } \\
\text { P. amboinensis }\end{array}$ & 39.3 & 3.3 & $74.0(10)$ & $8.0(2)$ \\
\hline 14 & $\begin{array}{l}19 \\
24\end{array}$ & $\begin{array}{l}\text { P. moluccensis } \\
\text { Cheilodipterus quinquilineata }\end{array}$ & 38.4 & 5.2 & $79.0(8)$ & $12.4(18)$ \\
\hline 15 & $\begin{array}{r}4 \\
6 \\
24\end{array}$ & $\begin{array}{l}\text { A. semipunctatus } \\
\text { A. phalaena } \\
\text { C. quinquelineata }\end{array}$ & 36.3 & 4.3 & $71.0(9)$ & $8.0(2)$ \\
\hline 16 & $\begin{array}{r}9 \\
22\end{array}$ & $\begin{array}{l}\text { Cirrhilabrus sp. } \\
\text { A. doederleini }\end{array}$ & 34.3 & 3.7 & $74.0(20)$ & $6.8(12)$ \\
\hline 17 & $\begin{array}{r}8 \\
15\end{array}$ & $\begin{array}{l}\text { Gobiodon quinquestrigata } \\
\text { Dascyllus aruanus }\end{array}$ & 34.0 & 4.1 & $71.0(14)$ & $0.0\{20\}$ \\
\hline 18 & $\begin{array}{l}24 \\
15\end{array}$ & $\begin{array}{l}\text { C. quinquelineata } \\
\text { D. aruanus }\end{array}$ & 32.4 & 4.0 & $72.0(19)$ & $12.5(20)$ \\
\hline
\end{tabular}

The 3 species in the other cluster at census No. 3 were Asteropteryx semipunctatus (Eleotridae), Amblygobius phalena (Gobiidae), and Pomacentrus sp. (Pomacentridae; cf. Allen 1975, p. 216). The pattern of fusion creating this cluster was the joining of $A$. semipunctatus and $A$. phalaena at similarity of $84 \%$ and the addition of Pomacentrus sp. at a similarity of $80 \%$. The history of association of these species is shown in Fig. $3 \mathrm{~B}$. They maintained a relatively high level of association $(\bar{X}=60.5 \% \pm 2.2 \mathrm{SE}$ ) for the whole period of the study, although at several censuses they were not fused with each other until after the inclusion of several (12 at census No. 19) other species.

Clusters which formed at greater than $80 \%$ similarity in census Nos. 4 and 9 (Table 1) both comprised Asteropteryx semipunctatus and Amblygobius phalena, 2 of the 3 -species set already examined. In fact, the history of association for these 2 species is usually higher $(\bar{X}=71.9 \% \pm 1.9 \mathrm{SE}$; Fig. 3B) than when Pomacentrus sp. is included as a third group member.

By continuing this sort of calculation for all the 46 
Fig. 4. (A) The association level at which Apogon gracilis joined with most other species. At 8 censuses $A$. gracilis was not present at all (shown as $\phi$ ), at 6 censuses it was the last species to fuse with all the others and at 6 other censuses it formed small clusters prior to fusing into a single large cluster with most other species. Number of species in each small cluster is indicated by the solid circles number of species related to diameter of circle) and the similarity among members of that small cluster is given as a percentage. (B) The association level at which Petroscirtes fallax joined with most other species. Notations as in (A)
A

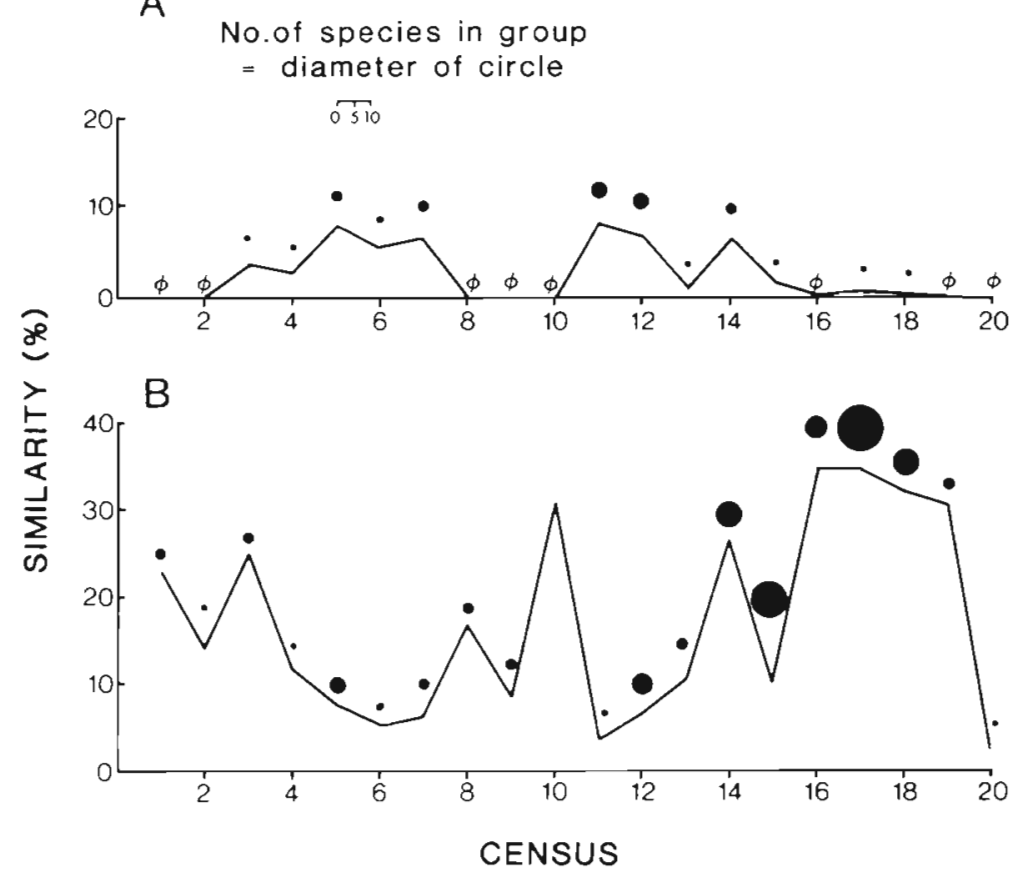

clusters with high (i.e. $>70 \%$ ) levels of association in Table 1 , we found the mean level of association across censuses for the species in each particular group (Table $3)$. Of the 46 groups in Table 1, only 18 were unique and only 6 of these averaged greater than $50 \%$ similarity over the duration of the study. Three of these 6 have been discussed, 2 others have some of the same species in common (Asteropteryx semipunctatus with Coris variegata (Labridae) and these 2 with Amblygobius phalaena), and the third is a 2 species group consisting of Coris variegata and Ecsenius mandibularis (Blenniidae).

At all censuses there were some groups that did not fuse with most other species until similarity values of less than $15 \%$ were reached (Table 2). These usually involved the addition of 1 or 2 'small clusters' to the bulk of species. In 15 of the 20 censuses the 'small clusters' consisted of just 1 species. The question of interest is, are the species in the 'small clusters' the same from census to census?

The species making up the small clusters shown in Table 2 are Apogon gracilis and Apogon cyanosoma (Apogonidae), Petroscirtes fallax (Blenniidae), Eviota queenslandica (Eleotridae), Gobiodon okinawe (Gobiidae), and Dascyllus reticulatus (Pomacentridae). However, only 2 species had consistently different patterns of distribution to all other species. A. gracilis and $D$. reticulatus show little tendency to associate positively with other species. The way in which $A$. gracilis fuses with most other species at each census is shown in Fig. $4 \mathrm{~A}$

The 4 other species were sometimes distributed quite distinctively but, at other times, were strongly positively associated with large groups of others (Table 2). An example of the way such species behave is illustrated for Petroscirtes fallax (Blenniidae) in Fig. 4B.

\section{Significance under a random placement model}

Species groupings obtained from the simulations ranged from strongly positive (e.g. $94 \%$ at census No. 3) to strongly negative (e.g. $<1 \%$ at census No. 12) as had those from the observed data. At each census, however, the average association among members of a simulated cluster was higher (range 65 to $73 \%$ for 20 censuses) than that for the real clusters (range 42 to $50 \%$ for 20 censuses). This implies that, on average, the observed species groupings are less similar than those generated under our null model.

A more detailed analysis of the 46 clusters in the field data which formed with greater than $70 \%$ similarity (Table 1), indicated that 3 were significantly less, 3 significantly more and 40 not significantly different from that expected under the null model. We point out, however, that 2 or 3 significant groupings could be expected on the basis of chance alone when 46 separate $t$ tests are done. This analysis indicates that, in most cases, clusters that form at greater than $70 \%$ similarity can still be attributed to chance associations of their component species.

We examined the pattern of actual association of the species in all the clusters with greater than $70 \%$ similarity in at least 1 census (listed in Table 1) to determine 
Table 4. Significance of the association in each of 18 groups of species identified as sometimes strongly associated (Table 1). Listed for each species group is the number of censuses at which it is more closely associated (< null), less closely associated (> null) or not significantly different in degree of association (ns) to that predicted by our null model of random recruitment to reefs ( 2 -tailed $t$-test, $\mathrm{df}=14, p<0.05$, in all cases shown as significant). Note that Gobiodon quinquestrigata was not present at one census

\begin{tabular}{|c|c|c|c|c|c|}
\hline Group & \multicolumn{2}{|c|}{ Species (reference no. and name) } & $<$ Null & $>$ Null & ns \\
\hline 1 & $\begin{array}{r}4 \\
6 \\
24\end{array}$ & $\begin{array}{l}\text { Asteropteryx semipunctatus } \\
\text { Amblygobius phalaena } \\
\text { Cheilodipterus quinquilineata }\end{array}$ & 18 & - & 2 \\
\hline 2 & $\begin{array}{l}13 \\
17\end{array}$ & $\begin{array}{l}\text { Acanthochromis polyacanthus } \\
\text { Pomacentrus amboinensis }\end{array}$ & 18 & - & 2 \\
\hline 3 & $\begin{array}{l}13 \\
22\end{array}$ & $\begin{array}{l}\text { A. polyacanthus } \\
\text { Apogon doederleini }\end{array}$ & 15 & - & 5 \\
\hline 4 & $\begin{array}{r}9 \\
22\end{array}$ & $\begin{array}{l}\text { Cirrhilabrus sp. } \\
\text { A. doederleini }\end{array}$ & 15 & - & 5 \\
\hline 5 & $\begin{array}{l}15 \\
24\end{array}$ & $\begin{array}{l}\text { Dascyllus aruanus } \\
\text { C. quinquilineata }\end{array}$ & 15 & 1 & 4 \\
\hline 6 & $\begin{array}{l}19 \\
24\end{array}$ & $\begin{array}{l}\text { Pomacentrus moluccensis } \\
\text { C. quinquilineata }\end{array}$ & 13 & - & 7 \\
\hline 7 & $\begin{array}{r}7 \\
19\end{array}$ & $\begin{array}{l}\text { Gobiodon okinawe } \\
\text { P. moluccensis }\end{array}$ & 12 & - & 8 \\
\hline 8 & $\begin{array}{l}12 \\
21\end{array}$ & $\begin{array}{l}\text { Thalassoma lunare } \\
\text { Scarus spp. }\end{array}$ & 10 & 1 & 9 \\
\hline 9 & $\begin{array}{r}4 \\
20 \\
12\end{array}$ & $\begin{array}{l}\text { A. semipunctatus } \\
\text { Pomacentrus } \mathrm{sp} \text {. } \\
T \text { lunare }\end{array}$ & 9 & - & 11 \\
\hline 10 & $\begin{array}{r}8 \\
15\end{array}$ & $\begin{array}{l}\text { Gobiodon quinquestrigata } \\
\text { D. aruanus }\end{array}$ & 7 & 1 & 11 \\
\hline 11 & $\begin{array}{r}1 \\
21\end{array}$ & $\begin{array}{l}\text { Atrosalarius fuscus } \\
\text { Scarus spp. }\end{array}$ & 6 & - & 14 \\
\hline 12 & $\begin{array}{l}4 \\
6\end{array}$ & $\begin{array}{l}\text { A. semipunctatus } \\
\text { A. phalaena }\end{array}$ & 5 & - & 15 \\
\hline 13 & $\begin{array}{r}1 \\
17\end{array}$ & $\begin{array}{l}\text { A. fuscus } \\
\text { P. amboinensis }\end{array}$ & 5 & - & 15 \\
\hline 14 & $\begin{array}{c}4 \\
6 \\
20\end{array}$ & $\begin{array}{l}\text { A. semipunctatus } \\
\text { A. phalaena } \\
\text { Pomacentrus sp. }\end{array}$ & 3 & - & 17 \\
\hline 15 & $\begin{array}{r}2 \\
10\end{array}$ & $\begin{array}{l}\text { Ecsenius mandibularis } \\
\text { Coris variegata }\end{array}$ & 3 & - & 17 \\
\hline 16 & $\begin{array}{l}11 \\
12\end{array}$ & $\begin{array}{l}\text { Labroides dimidiatus } \\
T \text {. lunare }\end{array}$ & 2 & - & 18 \\
\hline 17 & $\begin{array}{r}4 \\
6 \\
10\end{array}$ & $\begin{array}{l}\text { A. semipunctatus } \\
\text { A. phalaena } \\
\text { C. variegata }\end{array}$ & 1 & - & 19 \\
\hline 18 & $\begin{array}{r}4 \\
10\end{array}$ & $\begin{array}{l}\text { A. semipunctatus } \\
\text { C. variegata }\end{array}$ & 1 & - & 19 \\
\hline
\end{tabular}

if they were significantly tighter or looser at other censuses than expected by chance.

Apart from the 3 occasions already identified when clusters were tighter than expected by chance, none of these groupings was closer than we expected by chance in any other census (Table 4). Indeed, there were many instances in which identified clusters of species were less strongly associated than expected by chance. For example, the association between Atrosalarius fuscus and Pomacentrus amboinensis was less close than expected by chance at 5 censuses, and not different from chance at the other 15 censuses (Table 4 ; Fig. 5).

A similar examination was made of the clustering of the 2 species identified as consistently negatively associated with other species. Apogon gracilis and Dascyllus reticulatus proved on all but 2 occasions to be significantly less closely associated with other species than expected by chance. Under our null model, $A$. gracilis fused with most other species at an average level of 

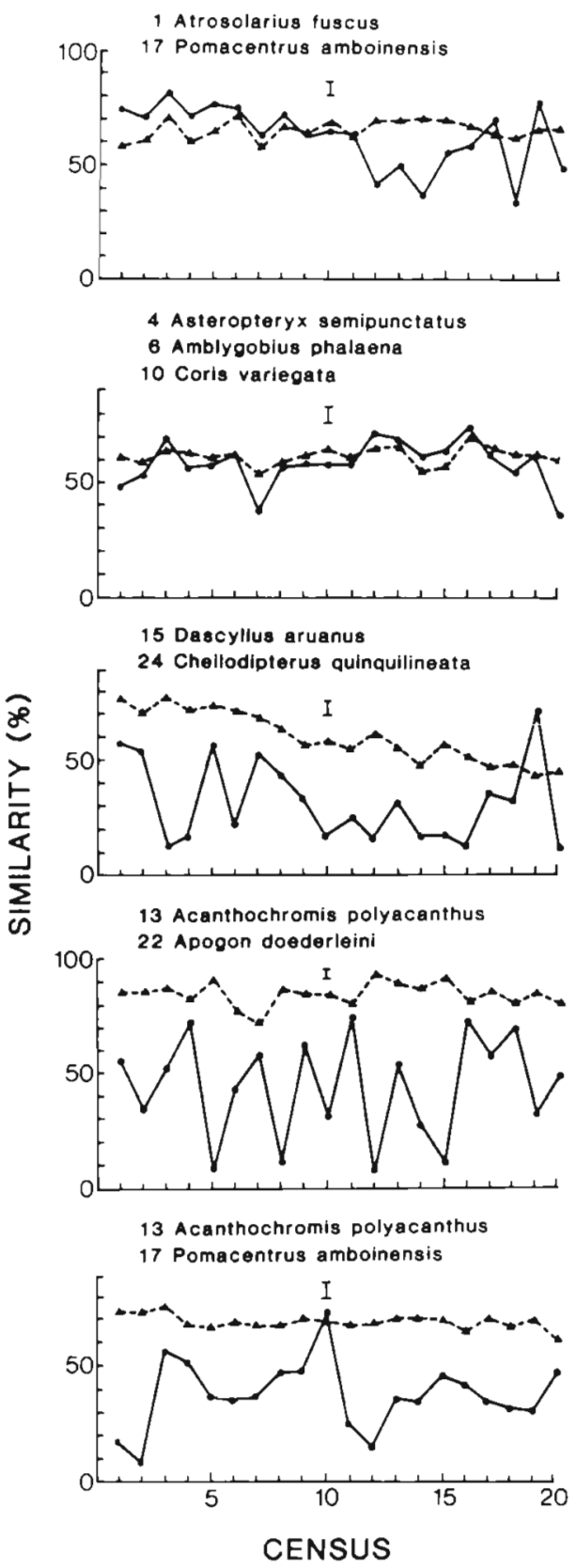

Fig. 5. Five examples of the comparisons between real (solid line) and random (dashed line) clusters listed in Table 4 Species names and reference numbers in each cluster are indicated. Error bars are the maximum $95 \%$ confidence limits for each cluster $(n=15)$

$57 \%$ similarity ( $3 \%$ in reality) and D. reticulatus did so at an average of $38 \%$ similarity $(10 \%$ in the field data).

\section{DISCUSSION}

It is a widespread expectation among ecologists that assemblages of species are organized. Rules of organi- zation are often anticipated which determine the diversity, the patterns of trophic interactions, and the ecological relationships among guilds of trophically similar species. Diamond (1975) referred to such 'assembly rules' in his analyses of the distribution of the bird species of the Bismark archipelago. At its most extreme, this expectation of organization becomes an expectation of order, of an equilibrial stable state at which the community resides.

In recent years a number of studies have been done which question the degree of organization to be expected in communities, and this area of ecology has seen considerable controversy (see papers in Strong et al. 1984, Diamond \& Case 1986). Assemblages of fish on coral reefs have provided an ideal system in which to explore such questions because they are rich in species and amenable to detailed observation and field experimentation.

Because local assemblages, such as occur on small patch reefs, are built up predominantly through the recruitment to the local site of small larvae settling from the plankton, they are also expected to be ones in which biotic interactions among residents and between residents and setting larvae will play a major structuring role (Smith 1978). That is, they are systems in which clearly defined assembly rules should be detectable.

Our studies of assemblages of reef fish on small patch reefs have largely failed to find such rules (Sale \& Dybdahl 1975, 1978, Sale 1980b, Sale \& Douglas 1984, Sale \& Steel 1986). Others have had similar difficulty (Talbot et al. 1978) or have drawn conclusions which we believe go beyond their data ( see discussion in Sale 1980a, 1984, Sale \& Williams 1982).

One aspect of organization which has received only limited attention in analyses of reef fish assemblages has been the patterns of association of fish species. Simple correlation in occurrence of pairs of species among sites has been used (Sale \& Dybdahl 1975, 1978, Talbot et al. 1978) with little detection of patten. Cluster analysis has been used to relate sites in terms of the similarity of assemblages they support (Gladfelter et al. 1980), but not to examine associations among species. In the present paper we have used cluster analysis to examine associations among species in their use, over $10 \mathrm{yr}$, of a group of 20 undisturbed small patch reefs. If our assemblages are organized so that particular groups of species tend to occur together, our analyses should have identified those groups and the strength of their association. Our analyses have not done this, but we have uncovered several trends

Initially, we analysed the data census by census. In 8 censuses the results indicated a broad division of species into 2 or 3 groups, a commonly desired result in this type of analysis. The other 12 censuses yielded less satisfying and different patterns. If we had analysed 
these data at only one of these censuses we would have arrived at one or other different pattern of species associations and probably would have been drawn in different directions to explain the pattern observed. The continued analysis of the data showed that most of the pattern observed at any one census disintegrated with time. This result in itself is interesting. It shows a general lack of stability of large species associations which, in the specific terms of our study, indicates that few species persist in occupying the reefs in similar relative proportions over the period of the study. Whatever factor(s) are influencing the relative abundances of species on the reefs, they are not acting to the same degree for every species at all censuses.

Although no overall pattern of association was apparent, we identified 18 unique smaller groups that were highly associated at one or more times (Table 3). However, only 6 of these groups had above average association (i.e. $>50 \%$ ) and only one had a high level of association (i.e. $>70 \%$ ) over the duration of the study. The possible reasons for the continued association in these cases are numerous, but it may be possible to eliminate a few. The time-scale of the study may have been too short, relative to the longevity and survivorship of the species concerned. For example, the species may have occurred together initially by chance and remained associated simply because the abundances of any of them changed little over the course of the study. To examine this possibility we analysed the abundances of all of the 7 species in the 6 relevant clusters at each census.

With the possible exception of Pomacentrus sp., all species showed marked fluctuations in abundance over the period of the study, indicating continual loss and replacement of individuals (Fig. 6). The abundance of Pomacentrus sp. declined steadily to census No. 10 , suggesting little replacement, but then fluctuated for the rest of the study. Over the course of the study all the species showed at least a $100 \%$ change in abundance among censuses. The average percent change in abundance among censuses ranged from $17 \%$ for Pomacentrus ambionensis to $63 \%$ for Amblygobius phalaena. It seems, therefore, that in 20 censuses there was ample opportunity for change in distribution of fish among reefs because substantial additions and losses occurred. Direct information on longevity is not available for any of these 7 species. It is possible that some individuals of $P$. ambionensis and perhaps of Pomacentrus sp. may have survived the duration of the study, but the changes seen in abundances ensure that few, if any, did so.

A second possible reason for the observed species associations is a similar affinity of the species concerned for particular reefs. The 20 reefs vary in structure and size, and the distributions of some species are apparently influenced by particular attributes of

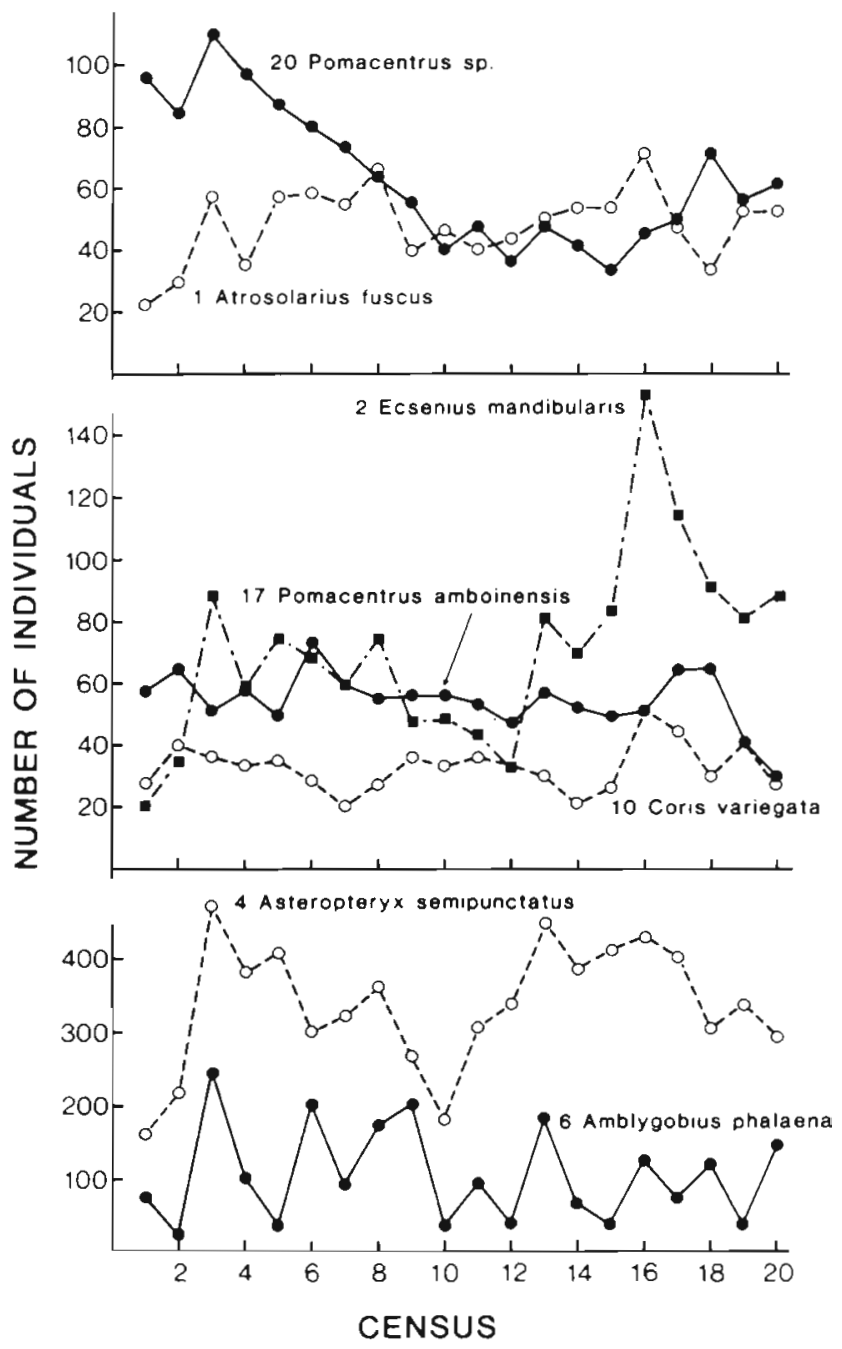

Fig. 6. Abundances summed over all patch reefs at each of 20 censuses for 7 species which were members of 6 groupings that formed at above average association for 20 censuses. Note the different scale in the last graph

habitat (Sale \& Douglas 1984, Sale \& Steel 1986). Another explanation is that the species associate with each other but do not necessarily show affinity for any particular patch reefs. Sweatman $(1982,1985)$ has demonstrated that larvae of 2 species of pomacentrid settle preferentially to sites containing resident conspecifics. Responses of this type to the presence of fish of other species may be possible but have not been demonstrated.

We examined the distribution of each species across the patch reefs at every census to see which of the above patterns was evident. This was done for each species by ranking its occurrence on the reefs from least to most abundant at each census and comparing the concordance of the ranks across time with Kendall's coefficient of concordance. All species had concordance values significantly greater than zero, although 
Table 5. Degree of concordance among censuses in the distribution among the 20 reefs of each of 7 species of fish. These species variously make up the 6 clusters which had above average association over the 20 censuses. The abundance of each species on a reef was used to rank the reefs in degree of attractiveness for it. A value of $100 \%$ for Kendall's $W$ indicates complete concordance or identical ranking of the 20 reefs at each of the 20 censuses. The $\chi^{2}$ values allow a test of the significance (with $19 \mathrm{df}$ ) of the concordance found. The values are tested against a null hypothesis of $W=0$. All values are significant at $p<0.01$

\begin{tabular}{|clrr|}
\hline Species & (reference no. and name) & $W$ & $\chi^{2}$ \\
\hline 17 & Pomacentrus amboinensis & $74.6 \%$ & 283.6 \\
1 & Atrosalarius fuscus & $66.5 \%$ & 252.6 \\
4 & Asteropteryx semipunctatus & $60.0 \%$ & 228.0 \\
2 & Ecsenius mandibularis & $45.8 \%$ & 174.2 \\
6 & Amblygobius phalaena & $40.8 \%$ & 155.1 \\
10 & Coris variegata & $17.8 \%$ & 67.8 \\
20 & Pomacentrus sp. & $31.5 \%$ & 119.6 \\
\hline
\end{tabular}

values ranged from $18 \%$ to $75 \%$ concordance (Table 5). These results and inspection of the frequency distribution of individuals across patch reefs at each census (example in Fig. 7) lend support to the idea that the species are associated because they show affinity for the same patch reefs.

Affinity for the same reefs could be a result of any of several processes. Habitat preferences may lead species to discriminate among patch reefs at the time of settlement (Sale et al. 1984). This appears the most likely explanation for the positive association of Asteropteryx semipunctatus and Amblygobius phalaena, both of which use low, relatively level areas of the reefs, with sandy algal turfs. We find the other associations less easy to explain in this way. A tendency to settle on reefs already occupied by conspecifics (cf. Sweatman 1985) could prolong a pattern of distribution initially established by chance. Current regimes might also affect species similarly, delivering them to the same reefs at the time of settlement. Further research is needed on the choice of microhabitats, and the response to water movement, by fish at settlement.

The random placement model developed by Sale \& Steel (1986) demonstrated that chance settlement alone could account for a surprising proportion of the pattern seen in distribution of species among these 20 patch reefs. This model was used to generate the tests of associations found among groups of the 25 most common species examined in this paper. The most surprising result to emerge from this analysis of the data is that not only are tightly associated groups of species seldom more closely associated than expected by chance, but that even closely associated groups are often significantly less strongly associated than would be expected

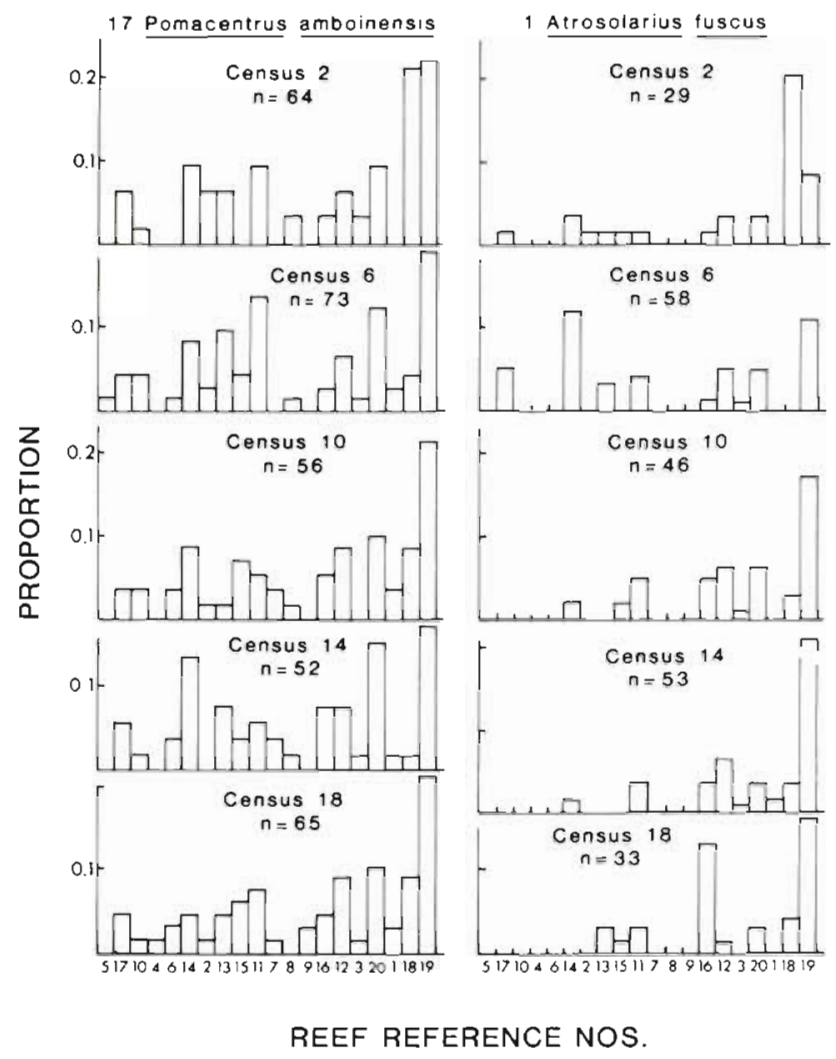

Fig. 7 Pomacentrus amboinensis and Atrosalarius fuscus. Relative frequency of individuals on patch reefs at each of 5 selected censuses. Concordance values (Table 5) for these and other species were calculated from raw data of this form. The reefs are arranged in order of increasing size, measured as surface area, Reef reference numbers (1 to 20) are retained for continuity with previous publications

by chance alone. This result may indicate that species are tending to avoid each other when recruiting to reefs or failing to survive very long in each other's presence. The various species may also respond in different ways to particular attributes possessed by the reefs, resulting in significantly different patterns of distribution.

Given that the 25 most common species analysed here include 8 species previously identified as behaving nonrandomly when recruiting to reefs (Sale \& Steel 1986), we currently favor the view that the fish are often less strongly associated than expected because of these differing responses to the patch reefs. Discriminating between this explanation and one based on negative interactions among species (competitive or predatory) will require experimental studies. The species in Table 5 are a useful group with which to begin.

Acknowledgements. This work was supported by grants to $P$. F. Sale from the Australian Research Grants Scheme. Field censuses were done with the assistance of R. Dybdahl, W. A. Douglas, T A. Jones and J. A. Guy. This is a contribution from the University of Sydney's One Tree Island Field Station. 


\section{LITERATURE CITED}

Allen, G. R. (1975). Damselfishes of the South Seas. T F. H Publications, Neptune City, NJ

Bohnsack, J. A., Talbot, F. H. (1980). Species packing by reef fishes on Australian and Caribbean reefs: an experimental approach. Bull mar Sci. 30: 710-723

Clifford, H. T., Stephenson, W. (1975). An introduction to numerical classification. Academic Press, New York

Connor, E. F., Simberloff, D. (1979). The assembly of species communities: chance or competition? Ecology 60 $1132-1140$

Diamond, J. M. (1975). Assembly of species communities. In: Cody, M. L., Diamond, J. M. (eds) Ecology and evolution of communities. Harvard Universtiy Press, Cambridge, $p$. $342-444$

Diamond, J. M., Case, $\Upsilon$ J. (eds.) (1986). Community ecology. Harper and Row, New York

Diamond, J. M., Gilpin, M. E. (1982). Examination of the 'Null models of Connor and Simberloff for species $\mathrm{CO}$ occurrences on islands. Oecologia (Berl.) 52: 64-74

Gladfelter, W. B., Odgen, J. C., Gladfelter, E. H. (1980) Similarity and diversity among coral reef fish communities: a comparison between tropical western Atlantic (Virgin Islands) and tropical central Pacific (Marshall Islands) patch reefs. Ecology 61 1156-1168

Goldman, B., Talbot, F. H. (1976). Aspects of the ecology of coral reef fishes. In: Jones, O. A., Endean, R., (eds.) Biology and geology of coral reefs, Vol. 3, Biology 2. Academic Press, New York, p. 125-154

Harper, C. W., Jr (1978). Groupings by locality in community ecology and paleoecology: tests of significance. Lethia 11: 251-257

Kohn, A. J., Riggs, A. C. (1982). Sample size dependence in measures of proportional similarity. Mar. Ecol. Prog. Ser. 9: $147-151$

MacArthur, R. H. Wilson, E. O. (1967). The theory of island biogeography. Princeton Univ. Press, Princeton. New Jersey

Magnusson, J. J. (1976). Managing with exotics - a game of chance. Trans. Am. Fish. Soc. 105: 1-9

Molles, M. C., Jr (1978). Fish species diversity on model and natural reef patches: experimental insular biogeography. Ecol. Monogr 48: 289-305

Pielou, E. C. (1984). The interpretation of ecological data, a primer on classification and ordination. Wiley-interscience, New York

Platt, W S., Weis, I. M. (1985). An experimental study of competition among fugitive prairie plants. Ecology 66: $708-720$

Rey, J. R. (1984). Experimental tests of island biogeographic theory. In: Strong, D. R., Simberloff, D., Abele, L. G., Thistle, A., (eds.) Ecological communities: conceptual issues and the evidence. Princeton Univ. Press, Princeton, New Jersey, p. 101-112

Riebesell, J. F. (1982). Arctic-alpine plants on mountain tops: Agreement with island biogeography theory. Am. Nat. 119: $657-674$

Sale, P. F. (1980a). The ecology of fishes on coral reefs. Oceanogr. mar. Biol. A. Rev. 18: 367-421

Sale, P. F. (1980b). Assemblages of fish on patch reefs - predictable or unpredictable? Environ. Biol. Fish. 5: 243-249

Sale, P. F. (1984). The structure of communities of fish on coral reefs and the merit of a hypothesis-testing, manipulative approach to ecology. In: Strong, D. R., Simberloff, D., Abele, L.G., Thistle, A. (eds.) Ecological communities: con- ceptual issues and the evidence. Princeton Univ. Press. Princeton, Now Jersey, p. 470-490

Sale, P. F., Douglas, W. A. (1981). Precision and accuracy of visual census techniques for fish assemblages on coral patch reefs. Environ. Biol. Fish. 5: 243-249

Sale, P. F., Douglas, W. A. (1984). Temporal variability in the community structure of fish on coral patch reefs and the relation of community structure to reef structure. Ecology 65: $409-422$

Sale, P. F., Douglas, W. A., Doherty, P. J. (1984). Choice of microhabitats by coral reef fishes at settlement. Coral Reefs 3: 91-99

Sale, P. F., Dybdahl, R. (1975). Determinants of community structure for coral reef fishes in an experımental habitat. Ecology 56: 1343-1355

Sale, P. F., Dybdahl, R. (1978). Determinants of community structure for coral reef fishes in isolated coral heads at lagoonal and reef slope sites. Oecologia (Berl.) 34: 57-74

Sale, P. F., Steel, W J. (1986). Random placement and the distribution of fishes among coral pätch reefs. Mar Ecol. Prog. Ser 28: 165-174

Sale, P. F., Williams, D. McB. (1982). Community structure of coral reef fishes: are the patterns more than those expected by chance? Am. Nat. 120: 121-127

Shulman, M. J., Ogden, J. C. Ebersole, J. P., McFarland, W. N., Miller, S. L., Wolf. N. G. (1983). Priority effects in the recruitment of juvenile coral reef fishes. Ecology 64: 1508-1513

Simberloff, D. (1974). Equilibrium theory of island biogeography and ecology. Ann. Rev. Ecol. Syst. 5: 161-182

Simberloff, D., Wilson, E. O. (1969). Experimental zoogeography of islands: the colonization of empty islands. Ecology 50: $278-296$

Smith, C. L. (1978). Coral reef fish communities: a compromise view. Environ. Biol. Fish. 3: 109-128

Smith, C. L., Tyler, J. C. (1972). Space resource sharing in a coral reef fish community. Nat. Hist. Mus. Los Angeles Cty Sci. Bull. 14: 125-170

Smith, C. L., Tyler, J. C. (1975). Succession and stability in fish communities of dome-shaped patch reefs in the West Indies. Am. Mus. Novit. 2572: 1-18

Sokal, R. R., Rohlf, F. J. (1981). Biometry: the principles and practice of statistics in biological research. 2nd edn. W. H. Freeman and Co., San Francisco

Sneath, P. H. A., Sokal, R. R. (1973). Numerical taxonomy. W. $H$. Freeman and Co., San Francisco

Strauss, R. E. (1982). Statistical significance of species clusters in association analysis. Ecology 63: 634-639

Strong, D. R., Rey, J. R. (1982). Testing for MacArthur-Wilson equilibrium with the arthropods of the miniature Spartina archipelago at Oyster Bay, Florida. A.m. Zool. 22: 355-360

Strong, D. R., Simberloff, D. S., Abele, L. G., Thistle, A. (eds.) (1984). Ecological communities: conceptual issues and the evidence. Princeton Univ. Press, Princeton, New Jersey

Sweatman, H. P. A. (1983). Influence of conspecifics on choice of settlement sites by larvae of two pomacentrid fishes (Dascyllus aruanus and D. reticulatus). Mar. Biol. 75: 225-230

Sweatman, H. P. A. (1985). The influence of adults of some coral reef fishes on larval recruitment. Ecol. Monogr. 55: 469-485

Talbot, F. H., Russell, B.C., Anderson, G. R. V. (1978). Coral reef fish communities: unstable high-diversity systems? Ecol. Monogr. 49: 425-440

Wilcox, B. A., Murphy, D. D., Ehrlich, P. R., Austin, G. T. (1986). Insular biogeography of the montane butterfly faunas in the Great Basin: comparison with birds and mammals. Oecologia (Berl.) 69: 188-194 